\title{
The Influence of Social Commerce on Consumer Decisions
}

\author{
Hettiarachchi H.A.H. ${ }^{1}$, Wickramasinghe C.N. ${ }^{2}$, Ranathunga S. ${ }^{3}$ \\ 1, 2 Department of Commerce and Financial Management, University of Kelaniya \\ ${ }^{3}$ Department of Computer Science and Engineering, University of Moratuwa
}

Sri Lanka

\begin{abstract}
Today, comprehending consumer behavior is becoming dynamically challenging with the emergence of social commerce. Business organizations are now striving to convince consumers by exploiting the advantage of social support empowered by online social networks. Importantly, social ties in such online social networks facilitate trust as the most compelling benefit while alleviating the perceived risk, which happened to be the major concerns with electronic commerce over the years. This research study is aimed at understanding the impact of social commerce on the consumer behavior, particularly consumer decision-making stages. Hence, this research was conducted as a quantitative study involving a cross-sectional survey and gathered valid responses from Facebook users. Structural Equation Modeling (SEM) was used to analyze data and test hypotheses. The findings exhibited significant positive effects from social commerce on all the consumer decision-making stages namely; need recognition, information search, alternative evaluation, purchase decision and post-purchase decision. Therefore, this study highlights the importance of employing an appropriate social commerce strategy for business organizations.
\end{abstract}

Keywords: Consumer Decision-Making Stages, Online Social Networks, Social Commerce, Social Commerce Constructs, Social Support

\section{Introduction}

Web 2.0 is the groundbreaking technological advancement that resulted to embark the virtual social communities. Unlike in the past, today consumers are highly exposed to different social media technologies in which extreme popularity is residing with the Online Social Networks (OSNs). Consequently, people started to seamlessly connecting each other by embracing the OSNs in an unprecedented way. Enabling users to instantly create content and the ability to seamlessly interact with others are the most salient features that accelerated the acceptance and usage of OSNs. Besides, OSNs are becoming a beneficial platform for business organizations to build their presence. Notably, OSN platforms are now highly recognized as commercialized platforms equipped with virtual social interactions. Thus, academia and practitioners coined the term as "Social
Commerce" to name this technologically enabled phenomenon.

It is empirically evident that the Web 2.0 , primarily including OSNs has a significant impact on our behavior. In fact, from a commercial perspective, it has extended its impact on offline and online purchasing decisions of consumers (e.g., Forman, Ghose \& Wiesenfeld, 2008[1]; Hajli, 2015[2]; Han \& Windsor, 2011[3]; Kwahk \& Ge, 2012[4]; Stephen \& Galak, 2012[5] ; Wang \& Yu, 2017[6]). Moreover, it is acknowledged that equipping strongly with social support, OSNs led to strengthen ecommerce acceptance by building trust and minimizing perceived risk. Therefore, social commerce is no more a new phenomenon, thus envisioned to be among the salient driving forces of the business domain. It was firmly accepted the fact that among the other related fields, this could be the increasingly appealing research area (e.g.,

${ }^{1}$ Corresponding author. Email: harshaka@kln.ac.lk

Copyright (C) 2018, the Authors. Published by Atlantis Press.

This is an open access article under the CC BY-NC license (http://creativecommons.org/licenses/by-nc/4.0/). 
Khang, Ki \& Ye, 2012[7]; Liang \& Turban, 2011[8]; Lin, Li \& Wang, 2017[9]; Zhang \& Benyoucef, 2016[10]).

Marketers are highly keen on analyzing the consumer behavior than the past due to evolving nature of intense competition. Importantly, understanding consumer decision-making process stages for any product, service or event is conceived to be among the fundamentals of analyzing consumer behavior. Precisely, examining the influence of OSNs on consumer behavior is imperative for marketers' decisions. Nevertheless, there is a dearth of research conducted to investigate the impact of social commerce on consumer decision-making process stages namely; need recognition, information search, alternative evaluation, purchase decision and post-purchase behavior. Zhang and Benyoucef (2016) ${ }^{[10]}$ stated the existence of a theoretical and an empirical gap in investigating the above phenomenon. Yadav, de Valck, Hennig-Thurau, Hoffman and Spann, (2013)[11] stated the importance of examining the influence of social commerce on consumer decision-making process stages for firms to leverage.

Therefore, responding to the aforementioned under-explained phenomenon, this study aims to explore the effects of social commerce on the consumer decision-making process stages. The remainder of this paper is organized as follows. The next section mainly reviews social commerce, social support and consumer decision making stages. Subsequently, research model and respective hypotheses are presented prior to emphasizing the methodology. Afterward, collected data were analyzed and interpreted. Finally, the implications, recommendations and future research directions are discussed at the conclusion of paper.

\section{Literature Review and Theoretical Foundation}

\subsection{Social Media and Online Social Networks}

Social media including OSNs has become the most popular online destination in recent years. Apparently, OSNs are a key cluster of "Social Media" umbrella. OSNs allow a user to create a profile and thereby facilitate to build connections with other users within the community (Boyd \& Ellison, 2007[12]; Kaplan \& Haenlein, 2010[13]). Importantly, such OSNs allow communities of users to gather online, share information, knowledge, and opinions (Kaplan \& Haenlein, 2010[13]). The rapid penetration of OSNs has fundamentally changed the way people manage information about their personal and professional lives. Today, OSNs are increasingly attracting researchers as a platform for recognizing emerging social behavioral changes (Cachia, Compañó, \& Da Costa, 2007[14]).

\subsection{Facebook as an Online Social Network}

Facebook defines itself as "a social utility that helps people share information and communicate more efficiently with their friends, family and coworkers" 2 . Most notably, the advent of OSNs including Facebook attracted millions of users worldwide (Boyd \& Ellison, 2007[12]). Among the other OSNs, Facebook is the most popular OSN and contributes significantly to a larger proportion of overall Internet traffic. In fact, Facebook had tremendous growth in monthly active users surpassing other OSNs during the last few years (Richter, 2016[15]). As of June 2016, Facebook subscribers were approximately $22.9 \%$ of total world population (Internet World Stats, 2016a[16]).

\subsection{Social Commerce}

OSN technologies gave birth to the social commerce as a new phenomenon in the business domain. Liang and Turban (2011)[8] stated that social commerce utilizes Web 2.0 driven social technologies and infrastructure to aid interactions and user contributions in an online context to support consumers' acquisition of products and services. Lin et al. (2017)[9] defined social commerce as "any commercial activities facilitated by or conducted through the broad social media and Web 2.0 tools in consumers' online shopping process or business interaction with their customers".

It is evident that OSNs are revolutionizing the business landscape allowing consumers to be more informative and interactive (Song \& Yoo, 2016[17]; Wang \& Yu, 2017[6]). In fact, such OSN applications comprised with Facebook placed the consumers in a more dynamic role as market influencers and enabled them to reach (and be

2 Retrieved from https://www.facebook.com/peering/ 
reached by) everyone, anywhere and anytime (Hennig-Thurau, Malthouse, Friege, Gensler, Lobschat, Rangaswamy \& Skiera, 2010[18]). Now, business organizations tend to firmly acknowledge that social media is an inevitable facet of the marketing strategy. Hence, it is recommended to build the business presence on social media platforms (Heinrichs, Lim, J. \& Lim, K., 2011[19]; Osei \& Abenyin, 2016[20]). Busalim and Hussin $(2016)^{[21]}$ highlighted that with a new paradigm of conducting commerce using social media, social commerce is to be a promising new area of research. Unique characteristics of social commerce enable to strengthen relationships with customers allowing business organizations to achieve desirable economic boosts and successful marketing (Amblee \& Bui, 2011[22]; Hajli \& Sims, $2015^{[23]}$; Michaelidou, Siamagka \& Christodoulides, 2011[24]). Facebook has been chosen by the marketers as the most important OSN over the others and are planning on increasing the utilization of Facebook to achieve marketing objectives (Stelzner, 2016[25]).

\subsection{Social Commerce and Social Support}

How a person experiencing about being cared for, being responded to and being helped by people as a member of a community is known as social support (Ali, 2011[26]; Cobb, 1976[27]). The literature claims that the existence of social support in both offline and online environment has a significant impact on the consumer behavior. Specially, members of online communities involve and support each other that ultimately influential in shaping the consumer behavior (Bagozzi \& Dholakia, 2002[28]; Ridings \& Gefen, 2004[29]). Further, Ridings and Gefen, (2004) ${ }^{[29]}$ stated that next generation of online business attracts new consumers predominantly supported by communities.

Li (2011)[30] asserted that user behavior is highly affected by motivations of similar users of OSNs than their own motivations. In fact, social support in social commerce ensures trust and minimizes perceived risk, thus eventually increasing the buying intention of consumers (Hajli, 2015[2]; Han \& Windsor, 2011[3]). Therefore, social support is inevitably relevant in understanding consumer behavior in social commerce research (Liang \& Turban, 2011[8]). Moreover, success of social commerce is mainly determined by the social support (Liang, Ho, Li \& Turban, 2011[31]; Rad \&
Benyoucef, 2011[32]; Wang \& Yu, 2017[6]; Zhang, Lu, Gupta \& Zhao, 2014[33]).

OSN technologies allow users to have social relationships with different people. Besides, OSNs enable users to observe decisions and opinions of close friends, family, colleagues and other users (Pan, MacLaurin \& Crotts, 2007[34]; Wang \& Yu, 2017[6]). Hajli (2015)[2] posited that members of such OSNs could communicate and share their consumption related experience using Social Commerce Constructs (SCCs) which include rating and reviews, recommendations and referrals, and forums and communities. In fact, SCCs are the key enablers of social support in OSNs (Hajli, 2013[35]).

SCCs are in a form of User Generated Content (UGC) and are perceived to be more reliable and appropriate than information provided by the marketers (Bernoff \& Li, 2008[36]; Fotis, Buhalis \& Rossides, 2012[37]) and traditional media (Goh, Heng \& Lin, 2013[38]). Apparently, consumers are more interested in UGC than the vendor made information (Ridings \& Gefen, 2004[29]). Besides, SCCs provide seller's inducement to be trustworthy (Hajli, 2013[35]). Importantly, people tend to consider and follow others' heuristic information (choices, opinions, etc.) to lessen the cognitive effort in making decisions and overcoming information overload (Bonabeau, 2004[39]; Simpson, Siguaw \& Cadogan, 2008[40]) which can profoundly facilitate by OSNs. SCCs could mitigate major limitations of online shopping, thus influence the consumer behavior (Akar \& Topçu, 2011[41]; Do-Hyung, Jumin \& Ingoo, 2007[42]).

\subsection{Social Commerce and Consumer Decision- Making}

Consumer decision-making process is a key aspect of consumer behavior. The five stages model of consumer decision-making process comprising need recognition, information search, alternative evaluation, purchase decision, and post-purchase decision is commonly accepted (e.g., Kotler \& Armstrong, 2016[43]; Kotler \& Keller, 2016[44]; Schiffman \& Wisenblit, 2015[45]). Importantly, marketers are expected to focus on all the stages of consumer decision-making process without concentrating only on purchase decision stage.

In general, OSNs are positively or negatively influence the effectiveness of consumer decision- 
making (Power \& Phillips-Wren, 2011[46]; Rad \& Benyoucef, 2011[32]; Wang \& Yu, 2017[6]). Many social commerce studies profoundly focused on consumer purchasing behavior (e.g., Hajli, 2015[2]; $\mathrm{Ng}, 2013[47]$; Wang \& Chang, 2013[48]; Wang, Yu \& Wei, 2012[49]). Nevertheless, Yadav et al. (2013) [11] argued that social commerce domain should encompass activities that occur before, during and after a focal transaction. Ultimatly, Yadav et al. (2013)[11] defined social commerce as an "exchange related activities that occur in or are influenced by, an individual's social network in computer-mediated social environments, where the activities correspond to the need recognition, prepurchase, purchase and post-purchase stages of a focal exchange." Similarly, Lin et al. (2017)[9] briefed that social commerce involves variety of commercial activities that could assist consumers' in the pre-purchase evaluation, shopping decisions, and post-purchase behavior. Further, Osei and Abenyin (2016)[20] and Zhang and Benyoucef (2016) ${ }^{[10]}$ affirmed the validity of using consumer decision-making process stages to investigate the impact of social commerce on consumer decisionmaking. Many scholars argued that providing a compelling consumer experience by incorporating social interactions in every stage of the consumer decision-making process is a pre-requisite for successful social commerce (e.g., Huang \& Benyoucef, 2013[50]; Yadav et al., 2013[11]; Zhou, Zhang \& Zimmermann, 2013[51]).

\section{Research Model and Hypothesis Development}

\section{Social Commerce and Need/Problem Recognition}

The social environment plays a major role in influencing consumer perceived needs (e.g., Bandura, 1977[52]). Particularly, OSNs motivate consumer needs and wants (Rad \& Benyoucef, 2011[32]). Importantly, OSNs facilitate consumers to observe SCCs promptly. Thus, OSNs act as source of inspiration and referral for consumers to become aware of the problem or need (Yadav et al., 2013[11]). Cox and Park (2014) ${ }^{[53]}$ affirmed that SCCs in OSNs attract consumers. Thus, researchers constructed the following hypothesis.

H1: SCCs have a positive effect on the need recognition (NR) stage of the consumer decision-making.

\section{Social Commerce and Information Search}

Xiang and Gretzel (2010) ${ }^{[54]}$ and Hennig-Thurau, et al. (2010) ${ }^{[18]}$ posited that OSNs enable users to disseminate their consumption related experiences with members. Hence, OSNs act as a source of information for potential consumers (Yadav et al., 2013[11]). Comprising predominantly with SCCs, OSNs play a distinctive role for consumers as a personal information source. Kotler and Armstrong (2016) ${ }^{[43]}$ acknowledged that personal sources are perceived to be more reliable and have a major influence on consumer behavior. Besides, OSNs are rich information sources as members tend to trust the opinions from their connections (Chu \& Kim, 2011[55]; Power \& Phillips-Wren, 2011[46]; Rad \& Benyoucef, 2011[32]). Moreover, such UGC is more reliable and relevant than information provided by the marketers (Bernoff \& Li, 2008[36]; Fotis et al., 2012[37]) and traditional media (Goh et al., 2013[38]). Thus, researchers built following hypothesis.

H2: SCCs have a positive effect on the information search (IS) stage of consumer decision-making.

\section{Social Commerce and Alternative Evaluation}

OSNs facilitate consumers to evaluate alternatives (Yadav et al., 2013[11]). In fact, consumers can access SCCs in OSNs that are perceived to be more reliable (Hennig-Thurau, Wiertz \& Feldhaus, 2012[56]; Wang \& Yu, 2017[6]; Rad \& Benyoucef, 2011[32]) enabling consumers to evaluate their choices. Importantly, unknown and anonymous SCCs reduce consumer perceived risk (HennigThurau et al., 2012[56]). Moreover, consumergenerated content over marketer-generated content is perceived to be trustworthy information (Bae \& Lee, 2011[57]) for consumers to rely when evaluating alternatives. Thus, researchers built following hypothesis.

H3: SCCs have a positive effect on the alternative evaluation (AE) stage of consumer decision-making.

\section{Social Commerce and Purchase Decision}

OSNs allow consumers to decide what, where and when to buy (Yadav et al., 2013[11]). The social support on OSNs is significantly influential to consumer purchasing decisions (Hajli, 2013[35]; 
Han \& Windsor, 2011[3]; Rad \& Benyoucef, 2011[32]; Wang \& Yu, 2017[6]). Similarly, Stephen and Galak (2012)[5] concluded that sales were influenced majorly by the socially earned media activities over the traditionally earned media. Further, Wang and $\mathrm{Yu}$ (2017)[6] argued that purchasing information provided by the members of OSNs can be a strong referral for later consumer purchasing decisions. SCCs in OSNs can provide useful and relevant information that increase the probability of making a better buying decision (Yadav et al., 2013[11]). Thus, researchers built following hypothesis.

H4: SCCs have a positive effect on the purchase decision (PD) stage of consumer decision-making.

\section{Social Commerce and Post-Purchase Decision}

OSNs enable consumers to share consumption experience and satisfaction via SCCs (HennigThurau, Gwinner, Walsh \& Gremler, 2004[58]). Besides, consumer could validate an opinion, helping or educating others, sharing, bonding, and expressing pride associated with a specific purchase in OSNs (Yadav et al., 2013[11]). Liang et al. (2011)[31] stated that social support on OSNs could boost the consumer loyalty. Moreover, observing SCCs significantly increase the likelihood of post-purchase behaviors in OSNs (Wang \& Yu, 2017[6]). Thus, researchers built following hypothesis.

H5: SCCs have a positive effect on the post-purchase decision (PPD) stage of consumer decision making.

\section{Research Methodology}

\subsection{Instrument Development}

This research study has six constructs: social commerce, need recognition, information search, alternative evaluation, purchase decision and postpurchase decision. A structured questionnaire was developed to measure above constructs and the items included (Appendix A) under those constructs were measured by using five-point Likert-scale. Four items for SCCs adapted from Hajli and Sims (2015)[23] and Shanmugam, Sun, Amidi, Khani and Khani, (2016)[59]. Consumer decision-making stages were measured by adapting four items per each stage from Power and Phillips-Wren (2011)[46], Rad and Benyoucef (2011)[32], Sachdeva (2015) ${ }^{[60]}$ and Yadav et al. (2013) $)^{[11] .}$

\section{Data Collection}

The responses were collected through an online survey questionnaire from Sri Lankan Facebook users. Facebook is the most popular OSN in Sri Lanka. There are approximately 4.2 million Facebook subscribers in Sri Lanka representing $20.1 \%$ of the population (Internet World Stats, 2016b[61]). Researchers gathered 214 valid responses. The post-hoc power analysis result for 214 respondents was within the standard adequacy level of 0.8 .

The majority of respondents were male representing $63 \%$ of the sample. $64 \%$ of respondents represent age category of $20-29$ years. $55 \%$ of respondents were unmarried at the time of survey. The majority of respondents hold bachelor's degree representing $48 \%$ of total responses followed by $36 \%$ holds a post-graduate qualification. Private sector employees were the major respondents representing $66 \%$ of the sample. Further, $33 \%$ of the survey respondents were spending less than an hour a day on the Facebook.

Importantly, respondents were asked to select the products, services and events that they were interested or experienced on Facebook. Consequently, entertainment category holds the majority of responses. Subsequently, fashion, clothing, footwear and accessories category followed by travel, leisure and accommodation category secured later positions.

\section{Data Analysis}

The researchers employed Structural Equation Modeling (SEM) to achieve the research objectives and data were analyzed using IBM AMOS 23.

\section{Measurement Model}

Researchers analyzed a measurement model using a confirmatory factor analysis (CFA) to assess the measurement quality of constructs. The measurement model consists of six latent factors. Researchers assessed the fitness of measurement model using reliability and validity indices. Cronbach's alpha and composite reliability (CR) scores were used to assess the reliability. As shown 
in Table 01, Cronbach's alpha values exceeded the acceptable threshold of 0.7 recommended by Nunnally (1979)[62] and CR values were higher than the recommended value of 0.7 by Hair, Black, Babin and Anderson (2009)[63]. Hence, results demonstrated adequate internal consistency. Both convergent validity and discriminant validity were examined to assess the construct validity. Convergent validity was confirmed by examining average variance extracted (AVE) values. As shown in Table 01, all AVE values were meeting the acceptable threshold of 0.5 recommended by Hair et al. (2009)[63].

Table 01: Convergent Validity and Reliability

\begin{tabular}{|c|c|c|c|c|c|}
\hline Constructs & Items & Factor Loadings & $\mathrm{CR}$ & AVE & $\begin{array}{l}\text { Cronbach's } \\
\text { Alpha }\end{array}$ \\
\hline \multirow[t]{4}{*}{ SCCs } & SCCs4 & 0.579 & \multirow[t]{4}{*}{0.783} & \multirow[t]{4}{*}{0.477} & \multirow[t]{4}{*}{0.774} \\
\hline & SCCs3 & 0.778 & & & \\
\hline & SCCs2 & 0.743 & & & \\
\hline & SCCs1 & 0.646 & & & \\
\hline \multirow{4}{*}{ NR } & NR4 & 0.801 & \multirow{4}{*}{0.832} & \multirow{4}{*}{0.623} & \multirow{4}{*}{0.868} \\
\hline & NR3 & 0.788 & & & \\
\hline & NR2 & 0.769 & & & \\
\hline & NR1 & 0.800 & & & \\
\hline \multirow[t]{4}{*}{ IS } & IS4 & 0.599 & \multirow[t]{4}{*}{0.832} & \multirow[t]{4}{*}{0.558} & \multirow[t]{4}{*}{0.820} \\
\hline & IS3 & 0.714 & & & \\
\hline & IS2 & 0.875 & & & \\
\hline & IS1 & 0.773 & & & \\
\hline \multirow[t]{4}{*}{$\mathrm{AE}$} & AE4 & 0.817 & \multirow[t]{4}{*}{0.912} & \multirow[t]{4}{*}{0.722} & \multirow[t]{4}{*}{0.911} \\
\hline & AE3 & 0.838 & & & \\
\hline & AE2 & 0.872 & & & \\
\hline & AE1 & 0.870 & & & \\
\hline \multirow[t]{4}{*}{ PD } & PD4 & 0.765 & \multirow[t]{4}{*}{0.864} & \multirow[t]{4}{*}{0.614} & \multirow[t]{4}{*}{0.878} \\
\hline & PD3 & 0.836 & & & \\
\hline & PD2 & 0.800 & & & \\
\hline & PD1 & 0.729 & & & \\
\hline \multirow[t]{4}{*}{ PPD } & PPD4 & 0.701 & \multirow[t]{4}{*}{0.880} & \multirow[t]{4}{*}{0.649} & \multirow[t]{4}{*}{0.860} \\
\hline & PPD3 & 0.780 & & & \\
\hline & PPD2 & 0.875 & & & \\
\hline & PPD1 & 0.855 & & & \\
\hline
\end{tabular}

Source: Research Data

Discriminant validity was confirmed as recommended by Chin (1998)[64]. As shown in Table 02, square roots of AVEs were greater than inter-construct correlations, thus demonstrating satisfactory discriminant validity. Further, factor loadings were examined to assess the convergent and discriminant validity. As shown in Table 01, factor loading values were exceeding the threshold of 0.5 as recommended by Hair et al. (2009) ${ }^{[63]}$ and were significant $(p<0.01)$ for all items under respective constructs.

\section{Model Fit}

The model fit was assessed using absolute, incremental and parsimony fit indices recognized by Hooper, Coughlan and Mullen (2008)[65]. Hence, Table 03 depicts recommended and actual values of model fit indices. The $\chi^{2 / d f}$ value met the acceptance criteria proposed by Tabachnick and Fidell (2007)[66]. The RMSEA value was conforming to the recommendation of Hooper et al. (2008)[65]. The AGFI value was satisfying as 
suggested by Westland (2015)[67]. The SRMR value was complying with the acceptable threshold recommended by $\mathrm{Hu}$ and Bentler (1999) [68]. The NNFI value was conforming to the satisfactory criteria by Hooper et al. (2008)[65]. The CFI value met the recommendation of $\mathrm{Hu}$ and Bentler (1999) [68]. The PNFI value was within the acceptance criteria as suggested by Mulaik, James, Van Alstine, Bennet, Lind and Stilwell (1989)[69].

After obtaining a fitted model, researchers produced standardized estimates of the model as shown in Figure 01.

\section{Hypothesis Testing}

Five hypotheses were constructed initially aligning with the objectives of the research. As shown in Table 04, the results confirm that SCCs is a significant predictor of need recognition, information search, alternative evaluation, purchase decision and post-purchase decision stage under $1 \%$ significance level. Therefore, this research concludes that SCCs has a significant positive impact on all the consumer decisionmaking stages.

Table 02: Discriminant Validity

\begin{tabular}{|l|c|c|c|c|c|c|}
\hline & SCCs & NR & IS & AE & PD & PPD \\
\hline SCCs & $\mathbf{0 . 6 9 1}$ & & & & & \\
\hline NR & 0.591 & $\mathbf{0 . 7 8 9}$ & & & & \\
\hline IS & 0.630 & 0.609 & $\mathbf{0 . 7 4 7}$ & & & \\
\hline AE & 0.596 & 0.617 & 0.691 & $\mathbf{0 . 8 4 9}$ & & \\
\hline PD & 0.539 & 0.622 & 0.656 & 0.719 & $\mathbf{0 . 7 8 3}$ & \\
\hline PPD & 0.600 & 0.551 & 0.640 & 0.677 & 0.601 & $\mathbf{0 . 8 0 6}$ \\
\hline
\end{tabular}

Source: Research Data

\section{Source: Research Data}

Table 03: Model Fit Indices

\begin{tabular}{|l|l|l|l|}
\hline Indices & $\begin{array}{l}\text { Threshold } \\
\text { Level }\end{array}$ & $\begin{array}{l}\text { M o d e I } \\
\text { Value }\end{array}$ & Decision \\
\hline \multicolumn{3}{|l|}{ Absolute Fit Indices } \\
\hline $\begin{array}{l}\text { Relative } \chi^{2} \\
(\chi 2 / \text { df })\end{array}$ & $>2.00$ & 2.39 & Satisfied \\
\hline RMSEA & $<0.08$ & 0.08 & Satisfied \\
\hline AGFI & close to 1 & 0.76 & Satisfied \\
\hline SRMR & $<0.08$ & 0.06 & Satisfied \\
\hline Incremental Fit Indices \\
\hline $\begin{array}{l}\text { N N F I } \\
\text { (TLI) }\end{array}$ & $>0.80$ & 0.89 & Satisfied \\
\hline CFI & $>0.90$ & 0.90 & Satisfied \\
\hline Parsimony Fit Indices \\
\hline PNFI & $\geq 0.50$ & 0.75 & Satisfied \\
\hline
\end{tabular}

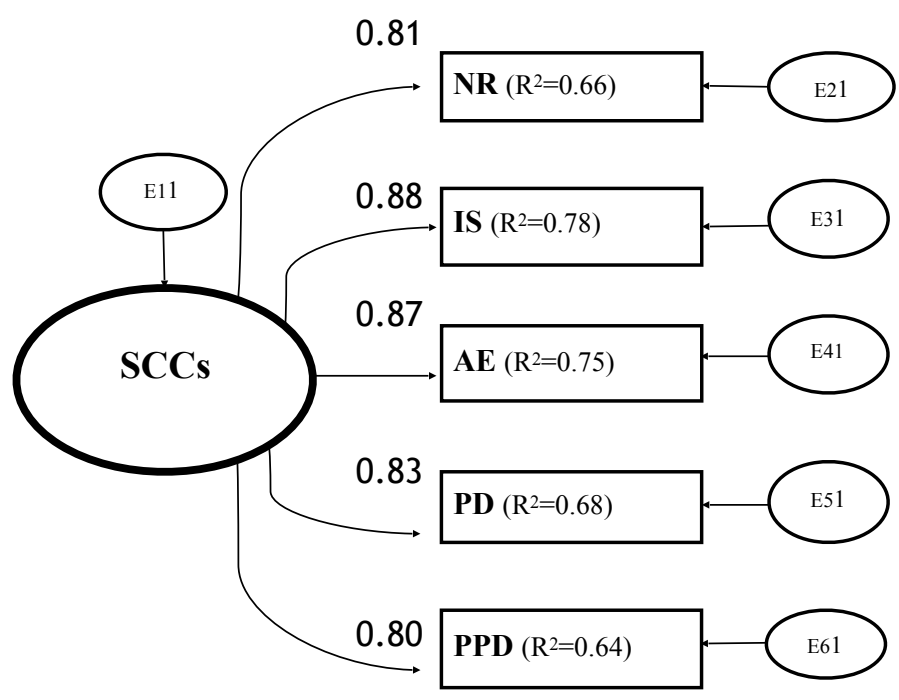

Figure 01: Standardized Estimates of the Model 
Table 04: Results of Hypothesis Testing

\begin{tabular}{|l|l|l|l|l|l|}
\hline Hypothesis & Effect & $\begin{array}{l}\text { P a t h } \\
\text { Coefficient } \\
\text { ( } \text { Value) }\end{array}$ & $\mathbf{R}^{\mathbf{2}}$ & $\begin{array}{l}\boldsymbol{P} \\
\text { Value }\end{array}$ & Decision \\
\hline H1 & SCCs -> NR & 0.81 & 0.66 & 0.000 & Accepted \\
\hline H2 & SCCs -> IS & 0.88 & 0.78 & 0.000 & Accepted \\
\hline H3 & SCCs -> AE & 0.87 & 0.75 & 0.000 & Accepted \\
\hline H4 & SCCs -> PD & 0.83 & 0.68 & 0.000 & Accepted \\
\hline H5 & SCCs -> PPD & 0.80 & 0.64 & 0.000 & Accepted \\
\hline
\end{tabular}

\section{Source: Research Data}

\section{Conclusion}

\subsection{Discussion}

Accompanied by a valid rationale, this research examined the influence of social commerce on consumer decision-making stages. Findings of the study ignited valuable theoretical and practical insights. Importantly, this research validates the definition of social commerce by Yadav et al. (2013) ${ }^{[11]}$ as all the research hypotheses (H1-H5) were accepted with adequate significance. Hence, it is imperative for business organizations to embrace and manage OSNs (e.g., Facebook) effectively to influence consumer decisions. In fact, business organizations could align their marketing and relationship-building efforts focusing on OSNs. Most of the companies are still in the infancy of implementing a successful social commerce strategy (Lin et al., 2017[9]). Thus, findings of this research deliberately emphasize the importance of a fully-fledged social commerce strategy.

Researchers strongly agree with the postulation of Kaplan and Haenlein (2010)[13] that social commerce is about participation, sharing and collaboration rather than straightforward advertising and selling. In fact, researchers have empirically proven that social support in OSNs has direct effects on the consumer decisions. Therefore, actively monitoring and managing social commerce conversations (i.e., SCCs) on OSNs is advisable. Notably, marketers should employ a social commerce strategy addressing all consumer decision-making stages. Consequently, business organizations will benefit by attracting potential consumers while retaining the loyalty of existing consumers. Particularly, OSNs as an earned media will lift sales at lowest marketing expenditure.

Adversely, disappointed consumers are inclined to post complaints on OSNs. In fact, once firms encourage consumers to be active on OSNs, they may have to live with the consequences of posting negative remarks. Besides, adverse SCCs are conceived to be destructive as such UGC are expected to amplify on OSNs. Therefore, crisis and reputation management is a vital aspect that marketers must incorporate into their social commerce strategy. Moreover, use of a specific analytic system to derive valuable insights (e.g., sentiment analysis) from OSNs is recommended by the researchers. Also, it is suggested to have designated employees with the primary objective of monitoring and managing OSNs. 
Researchers strongly believe that social commerce could drive organizations for consumer-oriented innovations. In fact, consumers can share their experience and ideas on OSNs from which organizations can learn (Lin et al., 2017[9]). Hence, social commerce creates an opportunity for consumers to be a part of new product development (Busalim \& Hussin, 2016[21]; Hajli, Lin, Featherman \& Wang, 2014[70]). Particularly, researchers accept the notion of Song and Yoo (2016)[17] that OSNs could be utilized more as an integrated promotion mix instead of a marketing communication channel.

\subsection{Limitations and Future Research Directions}

Future studies could be extended to other OSNs and regions as this research was confined to Sri Lankan Facebook users. The validated research model of this study can be applied for analyzing consumer behavior for a specific product or a service. Future researches in this context could incorporate qualitative or mixed research methodologies aimed at making strong inferences. This research analyzed the impact of social commerce on consumer decision-making stages without concerning inter-relatedness of decisionmaking stages owing to the novelty of the research phenomenon and the lack of literature with empirical support. Besides, some consumers might use social commerce for limited stages of the decision-making process. Prospectively, it is necessary to conduct a more comprehensive study in this context including other factors that may play an enabling, moderating or mediating role.

\section{References}

[1] Forman, C., Ghose, A., \& Wiesenfeld, B. (2008). Examining the Relationship Between Reviews and Sales: The Role of Reviewer Identity Disclosure in Electronic Markets. Information Systems Research, 19(3), 291-313.

[2] Hajli, N. (2015). Social commerce constructs and consumer's intention to buy. International Journal of Information Management, 35(2), 183-191.

[3] Han, B. O., \& Windsor, J. (2011). User's willingness to pay on social network sites. Journal of Computer Information Systems, 51(4), 31-40.

[4] Kwahk, K.-Y., \& Ge , X. (2012). The Effects of Social Media on E-commerce: A Perspective of Social Impact Theory. Hawaii International Conference on System Sciences. 45, pp. 1814-1823. Hawaii: IEEE.
[5] Stephen, A. T., \& Galak, J. (2012). The Effects of Traditional and Social Earned Media on Sales: A Study of a Microlending Marketplace. Journal of Marketing Research, 49(5), 624-639.

[6] Wang, Y., \& Yu, C. (2017). Social interaction-based consumer decision-making model in social commerce: The role of word of mouth and observational learning. International Journal of Information Management, 37(3), 179-189.

[7] Khang, H., Ki, E.-J., \& Ye, L. (2012). Social Media Research in Advertising, Communication, Marketing, and Public Relations, 1997-2010. Journalism \& Mass Communication Quarterly, 89(2), 279-298.

[8] Liang, T.-P., \& Turban, E. (2011). Introduction to the the Special Issue Social Commerce: A Research Framework for Social Commerce. International Journal of Electronic Commerce, 16(2), 5-13.

[9] Lin, X., Li, Y., \& Wang, X. (2017). Social Commerce Research: Definition, Research Themes and the Trends. International Journal of Information Management, 37(3), 190-201.

[10] Zhang, K. Z., \& Benyoucef, M. (2016). Consumer Behavior in Social Commerce: A Literature Review. Decision Support Systems, 86, 95-108.

[11] Yadav, M. S., de Valck, C., Hennig-Thurau, T., Hoffman, D. L., \& Spann, M. (2013). Social Commerce: A Contingency Framework for Assessing Marketing Potential. Journal of Interactive Marketing, 27(4), 311-323.

[12] Boyd, D. M., \& Ellison, N. B. (2007). Social Network Sites: Definition, History, and Scholarship. Journal of Computer-Mediated Communication, 13(1), 201-230.

[13] Kaplan, A. M., \& Haenlein, M. (2010). Users of the world, unite! The challenges and opportunities of Social Media. Business Horizons, 53(1), 59-68.

[14] Cachia, R., Compañó, R., \& Da Costa, O. (2007). Grasping the potential of online social networks for foresight. Technological Forecasting and Social Change, 74(8), 1179-1203.

[15] Richter, F. (2016, July 27). Competition Leaves Twitter in the Dust. Retrieved from Statista: https:// www.statista.com/chart/5358/twitters-user-growth-inperspective/

[16] Internet World Stat. (2016a, June). Facebook Users in the World. Retrieved from Internet World Stat: http:// www.internetworldstats.com/facebook.htm

[17] Song, S., \& Yoo, M. (2016). The role of social media during the pre-purchasing stage. Journal of Hospitality and Tourism Technology, 7(1), 84-99.

[18] Hennig-Thurau, T., Malthouse, E. C., Friege, C., Gensler, S., Lobschat, L., Rangaswamy, A., \& Skiera, B. (2010). The Impact of New Media on Customer 
Relationships. Journal of Service Research, 13(3), 311-330.

[19] Heinrichs, J. H., Lim, J. S., \& Lim, K. S. (2011). Influence of social networking site and user access method on social media evaluation. Journal of Consumer Behaviour, 10(1), 347-355.

[20] Osei, B. A., \& Abenyin, A. N. (2016). Applying the Engell-Kollat-Blackwell model in understanding international tourists' use of social media for travel decision to ghana. Information Technology and Tourism, 16(2), 1-20.

[21] Busalim, A. H., \& Hussin, A. R. (2016). Understanding social commerce: A systematic literature review and directions for further research. International Journal of Information Management, 36(6), 1075-1088.

[22] Amblee, N., \& Bui, T. (2011). Harnessing the Influence of Social Proof in Online Shopping: The Effect of Electronic Word of Mouth on Sales of Digital Microproducts. International Journal of Electronic Commerce, 16(2), 91-114.

[23] Hajli, N., \& Sims, J. (2015). Social commerce: The transfer of power from sellers to buyers. Technological Forecasting and Social Change, 94, 350-358.

[24] Michaelidou, N., Siamagka, N. T., \& Christodoulides, G. (2011). Usage, barriers and measurement of social media marketing: An exploratory investigation of small and medium B2B brands. Industrial Marketing Management, 40(7), 1153-1159.

[25] Stelzner, M. A. (2016). 2016 Social Media Marketing Industry Report. Social Media Examiner.

[26] Ali, H. (2011). Exchanging value within individuals' networks: Social support implications for health marketers. Journal of Marketing Management, 27(3-4), 316-335.

[27] Cobb, S. (1976). Social support as a moderator of life stress. Psychosomatic Medicine, 38(5), 300-314.

[28] Bagozzi, R. P., \& Dholakia, U. M. (2002). Intentional Social Action in Virtual Communities. Journal of Interactive Marketing, 16(2), 2-21.

[29] Ridings, C. M., \& Gefen, D. (2004). Virtual Community Attraction: Why People Hang Out Online. Journal of Computer-Mediated Communication, 10(1).

[30] Li, D. C. (2011). Online Social Network Acceptance: A Social Perspective. Internet Research, 21(5), 562-580.

[31] Liang, T.-P., Ho, Y.-T., Li, Y.-W., \& Turban, E. (2011). What Drives Social Commerce: The Role of Social Support and Relationship Quality. International Journal of Electronic Commerce, 16(2), 69-90.

[32] Rad, A. A., \& Benyoucef, M. (2011). A model for understanding social commerce. Journal of Information Systems Applied Research, 4(2), 63-73.
[33] Zhang, H., Lu, Y., Gupta, S., \& Zhao, L. (2014). What motivates customers to participate in social commerce? The impact of technological environments and virtual customer experiences. Information \& Management, 51(8), 1017-1030.

[34] Pan, B., MacLaurin, T., \& Crotts, J. (2007). Travel blogs and the implications for destination marketing. Journal of Travel Research, 46(1), 35-45.

[35] Hajli, N. (2013). A research framework for social commerce adoption. Information Management and Computer Security, 21(3), 144-154.

[36] Bernoff, J., \& Li, C. (2008). Harnessing the power of the oh-so-social web. MIT Sloan Management Review, 49(3), 36-42.

[37] Fotis, J., Buhalis, D., \& Rossides, N. (2012). Social Media Use and Impact during the Holiday Travel Planning Process. Berlin: Springer-Verlag.

[38] Goh, K. Y., Heng, C. S., \& Lin, Z. (2013). Social Media Brand Community and Consumer Behavior: Quantifying the Relative Impact of User- and MarketerGenerated Content. Information Systems Research, 24(1), 88-107.

[39] Bonabeau, E. (2004). The perils of the imitation age. Harvard Business Review, 82(6), 45-54.

[40] Simpson, P. M., Siguaw, J. A., \& Cadogan, J. W. (2008). Understanding the consumer propensity to observe. European Journal of Marketing, 42(1/2), 196-221.

[41] Akar, E., \& Topçu, B. (2011). An Examination of the Factors Influencing Consumers' Attitudes Toward Social Media Marketing. Journal of Internet Commerce, 10(1), 35-67.

[42] Do-Hyung, P., Jumin, L., \& Ingoo, H. (2007). The effect of on-line consumer reviews on consumer purchasing intention: the moderating role of involvement. International Journal of Electronic Commerce, 11(4), 125-148.

[43] Kotler, P., \& Armstrong, G. (2016). Principles of Marketing (16 ed.). NJ: Prentice-Hall.

[44] Kotler, P., \& Keller, K. L. (2016). Marketing Management (15 ed.). NJ: Prentice-Hall.

[45] Schiffman, L. G., \& Wisenblit, J. (2015). Consumer Behavior (11 ed.). NJ: Prentice-Hall.

[46] Power, D. J., \& Phillips-Wren, G. (2011). Impact of Social Media and Web 2.0 on Decision-Making. Journal of Decision System, 20(3), 249-261.

[47] Ng, C. S.-P. (2013). Intention to purchase on social commerce websites across cultures: A cross-regional study. Information \& Management, 50(8), 609-620.

[48] Wang, J.-C., \& Chang, C.-H. (2013). How online social ties and product-related risks influence purchase 
intentions: A Facebook experiment. Electronic Commerce Research and Applications, 12(5), 337-346.

[49] Wang, X., Yu, C., \& Wei, Y. (2012). Social Media Peer Communication and Impacts on Purchase Intentions: A Consumer Socialization Framework. Journal of Interactive Marketing, 26(4), 198-208.

[50] Huang, Z., \& Benyoucef, M. (2013). From ecommerce to social commerce: A close look at design features. Electronic Commerce Research and Applications, 12(4), 246-259.

[51] Zhou, L., Zhang, P., \& Zimmermann, H.-D. (2013). Social commerce research: An integrated view. Electronic Commerce Research and Applications, 12(2), 61-68.

[52] Bandura, A. (1977). Social Learning Theory. Englewood Cliffs, NJ: Prentice Hall.

[53] Cox, T., \& Park, J. H. (2014). Facebook marketing in contemporary orthodontic practice: A consumer report. Journal of the World Federation of Orthodontists, 3(2), e43-e47.

[54] Xiang, Z., \& Gretzel, U. (2010). Role of social media in online travel information search. Tourism Management, 31(2), 179-188.

[55] Chu, S.-C., \& Kim, Y. (2011). Determinants of consumer engagement in electronic word-of-mouth $(\mathrm{eWOM})$ in social networking sites. International Journal of Advertising: The Review of Marketing Communications, 30(1), 47-75.

[56] Hennig-Thurau, T., Wiertz, C., \& Feldhaus, F. (2012). Exploring the "Twitter Effect:" An Investigation of the Impact of Microblogging Word of Mouth on Consumers' Early Adoption of New Products. Working Paper, 10.2139/ssrn.2016548.

[57] Bae, S., \& Lee, T. (2011). Product Type and Consumers' Perception of Online Consumer Reviews. Electronic Markets, 21(4), 255-266.

[58] Hennig-Thurau, T., Gwinner, K. P., Walsh, G., \& Gremler, D. D. (2004). Electronic word-of-mouth via consumer-opinion platforms: What motivates consumers to articulate themselves on the Internet? Journal of Interactive Marketing, 18(1), 38-52.

[59] Shanmugam, M., Sun, S., Amidi, A., Khani, F., \& Khani, F. (2016). The applications of social commerce constructs. International Journal of Information Management, 36(3), 425-432.

[60] Sachdeva, R. (2015). A Scale to Assess the Efficacy of Consumer Decision Making. IUP Journal of Marketing Management, 14(2), 7.

[61] Internet World Stats. (2016b, June). Asia Marketing Research, Internet Usage, Population Statistics and Facebook Information. Retrieved from Internet World Stats: http:// www.internetworldstats.com/asia.htm
[62] Nunnally, J. C. (1979). Psychometric Theory. New York: McGraw-Hill.

[63] Hair, J. F., Black, W. C., Babin, B. J., \& Anderson, R. E. (2009). Multivariate Data Analysis (7 ed.). Chollerstrasse: Prentice Hall.

[64] Chin, W. W. (1998). The partial least squares approach for structural equation modeling. In G. A. Marcoulides, Modern Methods for Business Research (pp. 295-336). Mahwah, NJ: Lawrence Erlbaum Associates.

[65] Hooper, D., Coughlan, J., \& Mullen, M. (2008). Structural Equation Modelling: Guidelines for Determining Model Fit. Electronic Journal of Business Research Methods, 6(1), 53-60.

[66] Tabachnick, B. G., \& Fidell, L. S. (2007). Using Multivariate Statistics (05 ed.). New York: Allyn and Bacon.

[67] Westland, J. C. (2015). Structural Equation Models: From Paths to Networks. New York: Springer.

[68] Hu, L. T., \& Bentler, P. M. (1999). Cutoff criteria for fit indexes in covariance structure analysis: Conventional criteria versus new alternatives. Structural Equation Modeling: A Multidisciplinary Journal, 6(1), 1-55.

[69] Mulaik, S. A., James, L. R., Van Alstine, J., Bennet, N., Lind, S., \& Stilwell, C. D. (1989). Evaluation of Goodness-of-Fit Indices for Structural Equation Models. Psychological Bulletin, 105(3), 430-445.

[70] Hajli, N., Lin, X., Featherman, M., \& Wang, Y. (2014). Social Word of Mouth: How Trust Develops in the Market. International Journal of Market Research, 56(6), 673-689. 


\section{Appendix A: Operationalization}

\begin{tabular}{|c|c|c|c|}
\hline Construct & Item_\# & Description & Sources \\
\hline \multirow{4}{*}{$\begin{array}{l}\text { Social } \\
\text { Commerce } \\
\text { Constructs } \\
\text { (SCCs) }\end{array}$} & SCCs_01 & Ask on forums and communities for suggestions before purchase & \multirow{4}{*}{$\begin{array}{l}\text { Hajli and } \\
\text { Sims (2015) } \\
{[23] \text {, }} \\
\text { Shanmugam } \\
\text { et al. (2016) } \\
{[59]}\end{array}$} \\
\hline & SCCs_02 & Willing to recommend that is worth buying to friends/members & \\
\hline & SCCs_03 & Willing to share shopping experience as SCCs & \\
\hline & SCCs_04 & Like to use online recommendations and referrals to buy & \\
\hline \multirow{4}{*}{$\begin{array}{l}\text { Need } \\
\text { Recognition } \\
\text { (NR) }\end{array}$} & NR_01 & SCCs let realize needs & \multirow{20}{*}{$\begin{array}{l}\text { Power and } \\
\text { Phillips-Wren } \\
(2011)^{[46],} \\
\text { Rad and } \\
\text { Benyoucef } \\
(2011)^{[32],} \\
\text { Sachdeva } \\
(2015)^{[60]}, \\
\text { Yadav et al. } \\
(2013)^{[11]}\end{array}$} \\
\hline & NR_02 & SCCs prompt to purchase & \\
\hline & NR_03 & SCCs enable to re-evaluate needs & \\
\hline & NR_04 & SCCs remind the need & \\
\hline \multirow{4}{*}{$\begin{array}{l}\text { Information } \\
\text { Search } \\
\text { (IS) }\end{array}$} & IS_01 & Examine related SCCs when search for information & \\
\hline & IS_02 & Perceive SCCs as important source when search for information & \\
\hline & IS_03 & Perceive SCCs as reliable when search for information & \\
\hline & IS_04 & Don't make a purchase decision without examining SCCs & \\
\hline \multirow{4}{*}{$\begin{array}{l}\text { Alternative } \\
\text { Evaluation } \\
(\mathrm{AE})\end{array}$} & AE_01 & Check the related SCCs about alternatives before purchasing & \\
\hline & AE_02 & Consider related SCCs when evaluating the alternatives & \\
\hline & AE_03 & SCCs enable to evaluate the alternatives in mind & \\
\hline & AE_04 & Don’t finish evaluating alternatives without checking SCCs & \\
\hline \multirow{4}{*}{$\begin{array}{l}\text { P u r c h a s e } \\
\text { Decision } \\
\text { (PD) }\end{array}$} & PD_01 & SCCs influence choose to buy & \\
\hline & PD_02 & SCCs influence brand choice to buy & \\
\hline & PD_03 & SCCs influence the place of purchase & \\
\hline & PD_04 & SCCs influence the time of purchase & \\
\hline \multirow{4}{*}{$\begin{array}{l}P \text { o s t - } \\
\text { Purch a s e } \\
\text { Decision } \\
\text { (PPD) }\end{array}$} & PPD_01 & Check the related SCCs when problems arose after purchase & \\
\hline & PPD_02 & Express level of satisfaction experienced as SCCs & \\
\hline & PPD_03 & If satisfied express next purchase decision as SCCs & \\
\hline & PPD_04 & After purchase check related SCCs to evaluate decision & \\
\hline
\end{tabular}

